\title{
The neglected context: The growing impact of modernity on the South African population and its spiritual, economic and ecological consequences
}

\begin{abstract}
Author:
Klaus Nürnberger ${ }^{1}$

Affiliation:

${ }^{1}$ Senior Research Associate at the School of Religion and Theology, University of KwaZulu-Natal, South Africa

Correspondence to:

Klaus Nürnberger

Email:

nürnberger@telkomsa.net

Postal address:

21 Farmers Folly, Lynnwood, Pretoria 0081, South Africa

Dates:

Received: 14 Apr. 2012

Accepted: 14 Aug. 2012

Published: 06 Dec. 2012

How to cite this article: Nürnberger, K., 2012, 'The neglected context: The growing impact of modernity on the South African population and its spiritual, economic and ecological consequences', Verbum et Ecclesia 33(2), Art. \#733, 11 pages. $h t t p: / / d x . d o i$. org/10.4102/ve.v33i2.733
\end{abstract}

C 2012. The Authors. Licensee: AOSIS OpenJournals. This work is licensed under the Creative Commons Attribution License.
Humanity seems to be drifting like a rudderless raft towards a cataract. The main factors are the growth of the human population, the escalation of material expectations, the exploding discrepancies between affluent and marginalised population groups and the impact of these growth processes on the natural environment. The modern claim to mastery, ownership and entitlement and its spectacular successes has led to unprecedented power without a concomitant growth in responsibility. In spiritual and cultural terms, modernity undermines all traditional certainties, values and constraints. The South African population is engulfed in a messy transition from African traditionalist, to modern and postmodern assumptions. The most reticent citizens are the least competitive and the most marginalised. The Christian faith, rooted as it is in tradition and geared to spiritual concerns, is no match for the power of the modern mindset. To regain its redemptive relevance, it needs fundamental reconceptualisations. The article closes with a few starting points for such a project.

\section{Introduction}

It is a pleasure for me to dedicate this essay to Etienne de Villiers. We came to know each other about three decades ago when I visited Wellington on my annual University of South Africa (UNISA) group visits to the Western Cape. Many things have changed since those momentous times. But our common concern for the relevance of the Christian faith in the 'public space' has not changed. After my retirement, the monthly meetings of the Theological Society at the University of Pretoria, which he chaired, were a constant inspiration to me.

This essay was my contribution to the 2011 conference of the South African Theological Society that focused on a review of contextual theologies in South Africa. It argues that there is an overarching, formidable context that has not received the attention it deserves in many contextual theologies, that is, the precarious direction in which modernity leads humanity on its way into the future and the impact it has on traditional societies. South African churches, as well as the South African public at large, do not seem to have become conscious of the dangers involved to any sufficient extent.

For some 40 years perceptive ecological analysts have warned that humanity is heading blindfolded in a destructive and suicidal direction. Classics include the studies of the Club of Rome, beginning with Meadows, Meadows, Zahn and Milling (1972), and Mesarovic and Pestel (1974). They triggered a flood of academic analyses as well as the regular publications of organisations such as Green Peace, the World Watch Institute, the World Wildife Fund, the World Bank's annual World Development Reports, the Brundtland Report, the ongoing email publications of 350.org, $\mathrm{Al}$ Gore's video, 'An inconvenient truth' (2009) and many others. A useful summary of developments in the 20th century can be found in Garner (2000), chapter 2.

An exponential dynamic has evolved, within a few short centuries, that seems to be headed towards a catastrophic 'overshoot' within a few short decades. It has ecological, economic, social, cultural, psychological and religious dimensions. The problem is compounded in Africa by the consequences of the impact of modernity on indigenous forms of traditionalism in all spheres of life.

The aim of this article is to offer an overview of the problem as a whole, rather than attempt to do justice to detailed studies on specific issues. Overarching approaches tend to seem simplistic in the eyes of experts in particular fields, but that should not deter us. With ever increasing specialisation, interdisciplinary overviews have become ever more neglected and ever more important. Academia is in danger of losing sight of the forest for all the trees and getting lost in the process. 


\section{Some basic factors}

The first danger signal is population growth. The human population increased from about 5 million when humans first settled in villages and towns 6000 years ago, to about 200 million during the time of Jesus, 500 million in 1600, 600 million in 1700 (20\% growth), 900 million in 1800 (50\% growth), 1800 million in 1900 (100\% growth), about 6 billion in 2000 (230\% growth) and 7 billion now.

There are now 126 times as many people on earth as during the time of Jesus, 2000 years ago, and 14 times as many as at the time of the Reformation 500 years ago. The South African population increased almost tenfold from 5 million to close on 50 million within a single century (1900-2000). These are rough figures compiled to give an impression of a typical exponential growth curve. For detailed discussions see Foster (1994), Garner (2000) and Rosenberg (n.d.).

The second danger signal is the immense growth in material expectations that potentiates population growth. 'World consumption of commercial energy - most of it from nonrenewable resources - rose over 60 times between 1860 and 1985' (Foster 1994:19). Industrial production grew sevenfold during the second half of the 20th century and continues to grow exponentially (Ibid 20). There are vast discrepancies in income in the world today. In some very disadvantaged countries (such as Liberia and Burundi) Gross Domestic Income per capita may be about \$200, whilst in some more affluent countries (such as Germany and the United Kingdom) it may be roughly $\$ 40000$, thus, two hundred times as much as very disadvantaged countries (World Bank n.d.). If one takes account of the vast discrepancies within both wealthy and underprivileged countries the divergence becomes grotesque. Some of the richest men in the world own in excess of $\$ 60$ billion (Bey n.d.), whilst there are millions of people who do not know how they will feed their children.

The third danger signal is that the capacity of the earth to absorb this double whammy is reaching its limits. Yet growth processes continue unabated. The 'mature economies' are still hell-bent on ever further growth. Jobs lost through rationalisation and labour saving technology can only be made up through vigorous growth of the economy. The cycle of boom and recession shows that the capitalist system must grow or decline. When market demand is in danger of reaching saturation point, it must be artificially enhanced through aggressive marketing, easy credit and low interest rates.

Understandably the poor desperately want to catch up to the rich. The so-called 'emerging economies', notably China and India, are growing at a historically unprecedented pace. If the vast populations of China, India, Indonesia, Latin America and Africa would all reach the living standards taken for granted in Central Europe, the United States and Japan, the earth would no longer be able to cope. 'Human beings now use or co-opt some $40 \%$ of the food available to all land animals and about $45 \%$ of the available freshwater flows' (Ehrlich 1998:14). This is a tsunami not of seawater, but of humanity flooding the planet and destroying everything in its wake. Let us unravel some of the salient aspects of this process.

\section{The root of it all - modernity}

In what follows I am borrowing from my earlier work on this topic, notably Nürnberger (1999:186-226) and Nürnberger (2011:24-46). Modernity is driven by an emancipatory thrust. The modern human being claims to be the master, owner and beneficiary of reality. It rejects all kinds of authority: God, scripture, church, kings, princes, dictators, patriarchal and hierarchical systems, philosophical traditions, inherited worldviews, imposed ideologies, as well as their values, norms and demands. Socially, emancipation began with the aristocrats and continued to engulf one social formation after the other: the merchants, the slaves, the workers, the women and the children.

How did this come about? The confluence of a number of factors towards the end of the Middle Ages led Western civilisation into a profound disenchantment with authority. Philosophy had changed from Platonism (Augustine) to Aristotelianism (Thomas of Aquinas), then to Nominalism (William of Occam), and on to Empiricism. The 'Renaissance' rediscovered the excellence and cheerfulness of ancient Greek and Roman cultures. 'Humanists' amongst the Reformers, such as Erasmus of Rotterdam and Philip Melanchthon, enthusiastically embraced the treasures of Greek and Roman antiquity.

The Reformation undermined Catholic claims to divine truth and institutional legitimacy. Competition between Protestant and Catholic orthodoxies led to bloody religious wars and questioned the validity and credibility of both orthodoxies. The Thirty Years' War (1618-1648) devastated large parts of central Europe and led to large-scale disillusionment with organised and dogmatised religion. Journeys of discovery and global trade led to confrontations with alternative cultures. Encounters with Islam and Eastern religions problematised the Christian claim to divine revelation. Leading thinkers discovered the historical, situational, cultural and epistemological relativity of human insight, including the biblical scriptures.

The sun-centred cosmology of Copernicus displaced the earth-centred cosmology of Ptolemaeus. New discoveries and inventions turned prior knowledge of the world upside down. When all natural, institutional and spiritual foundations seemed to be shaking, leading thinkers turned from external authorities to their own experience of reality. That marked the birth of Western individualism and spiritualism. The watch words of the so-called Enlightenment are:

- think for yourself (rationalism)

- see for yourself (empiricism)

- pursue your own interests (liberal economy) 
- claim personal freedom and equality (human rights)

- have a say in your government (democracy)

- enjoy your life as long as it lasts (hedonism)

- develop an intimate relationship with your personal Saviour (Pietism).

Modernity manifests itself as modern science geared to evidence, technology geared to efficiency, commerce geared to profitability and consumerism geared to utility and pleasure. The achievements of modernity in terms of scientific knowledge, technological efficiency, commercial profitability, rising living standards and personal freedom have been spectacular. It is this glaring success that makes modernity particularly irresistible for people of traditional cultures.

Moreover, traditionalist modes of production can no longer feed the burgeoning population. The adoption of modern technologies has become a necessity. Nobody wants to return to premodern times and forego the immense improvements in the quality of life achieved by modernity, wherever it has taken root. We also need science and technology to solve the typical problems of the modern world. Yet we have to acknowledge that it was modernity that has led humanity into an unsustainable, destructive and self-destructive direction.

It is modernity that led to the population explosion. In prehistoric times humanity was conditioned to multiply rapidly to offset losses resulting from disease, wild animals and violent conflict. The rise of science and technology dramatically changed the balance of power between humans and nature (Durand 2010:54-56). Better hygiene, food, weapons, and medical care raised life expectancy. But all this happened without a concomitant reduction in the birth rate (Nürnberger 1999:210-211).

It is the impact of modernity on previously traditionalist societies, firstly in the West and then spreading to the rest of the world, that led to the escalation of material expectations. An attitude of sufficiency and contentment made way for a ferocious race to gain ever higher levels of material wealth and well-being. Competition has become the rule of the game, leading to the glaring and growing discrepancy in life chances we witness today (Nürnberger 2011:36-42).

It is modernity that led to the absolutisation of the human subject and the degrading of the objective world. The world has become a quarry to be mined for personal satisfaction, wealth, prestige and power, including one's own body, community, society and nature. This is the root of the ecological crisis. The exponential growth of power through science, technology and commerce, without a concomitant widening of horizons and growth of responsibility, has had disastrous consequences.

Spiritually, modernity led to new enslavements. Never in past history have humans enjoyed greater privileges (cars, cell phones, iPads, supermarkets, refrigerators, medical schemes, electricity, holidays, journeys) and never were people less satisfied with what they had than now. The emancipatory drive of modernity did not lead to genuine freedom. Aspiring to be free from accountability to higher authority, modern humans lost their transcendent foundations and became helpless victims of their own cravings, social pressures and natural forces. If you are responsible only to yourself, you are not responsible at all.

\section{The disruptive impact of modernity on traditionalist cultures}

In what follows I am borrowing from my earlier work (for instance, Nürnberger 1999, chapters 8 and 9, and Nürnberger 2007, chapters 2 and 5). What happens when modernity engulfs a population largely determined by a traditionalist mindset and culture? To answer this question we first have to spell out the contrast between the two approaches to reality. Traditionalism is a worldwide phenomenon. It has evolved into a great variety of forms over the last ten millennia of human history, including the plethora of African cultures and traditions, but also the premodern Western, American and Asian civilisations. Traditionalism, as we find it in Africa, is in many respects a mirror image of modernity. Let me mention a few pertinent instances:

1. Traditionalism has a dynamistic or an animistic worldview. Dynamism focuses on mysterious power flows; animism focuses on spirits with mysterious intentions. The secrets of reality are explored by divination and manipulated through rituals. The worldview of modernity, in contrast, is based on the behaviour of energy conglomerations that follow laws of nature, which can be analysed by experiment and manipulated by technology.

2. In traditionalism the highest value is healthy human relationships. In modernity it is the growth of material output, utility and pleasure.

3. Traditionalism is bound to a sacred past based on the sequence of generations. What previous generations thought and did is authoritative. Modernity leaves the past behind and tries to conquer the future. What previous generations thought or did is irrelevant.

4. Traditionalism is based on subservience to communal authority, concentrated in living elders and significant ancestors. Modernity is based on emancipation and the exercise of individual freedom.

5. For traditionalism the development and utilisation of individual gifts and opportunities to acquire individual wealth and power at the expense of the community is the greatest vice. Apart from its magical connotations, this is the essence of sorcery, which is severely punished. Modernity has elevated such individual initiative to the highest virtue, which is lavishly rewarded.

6. Traditionalism is characterised by a patriarchal and hierarchical community in which the roles and statuses of all members are precisely circumscribed according to gender, age and seniority. Transgressions of one's sphere of competence are not tolerated. Modernity allows individuals to establish vast collaborative relationships based on common interests, in which roles and statuses are allocated in terms of access to communication, expertise and efficiency. 
Obviously these are vast generalisations. They are only meant to give some profile to the contrast.

\section{Social consequences of the interaction}

Modernity has been able to overwhelm other cultures because it 'delivers the goods'. Being the dominant culture, it exerts considerable pressures to conform. Science disparages superstition, technology tolerates no inefficiency, commerce lures people into an acquisitive mentality, and the consumer culture elevates utility and pleasure to ultimate values. As a result there is a steady and rickety, but relentless drift from traditionalism to modernity.

Of course, current social reality does not present us with a pure form of either worldview, but with a messy mixture between the two. Yet certain contours of the interaction are readily discernible. Demographically, the lure of modernity has led to rapid urbanisation. But modern motives penetrate the most remote rural villages, firing up modern expectations, whilst traditionalist motives linger amongst Westernised urbanites and resurface in times of need (Ashforth 2005:3, 148-153).

This 'cultural lag', as sociologists call it, renders newcomers to the modern economy less motivated, less educated, less efficient, less connected and thus, on the whole, less competitive than people who are well established in the modern economy. The higher the level of education, status and wealth, the greater the modern component of the mix tends to become. The greater the traditionalist component, the greater the deficiencies in scientific knowledge, technological prowess, upward mobility and need satisfaction tend to be. The mix varies greatly between age, gender, race and cultural groups, leading to a build-up of resentment and tension in the society.

Meanwhile the consumer culture exercises increasing power over the imagination of the disadvantaged. The 'demonstration effect' of affluent lifestyles (strongly favoured by the media) weans less endowed people from traditionalist values and constraints. The advertising and entertainment industries deliberately and successfully foster discontent and avarice for the sake of higher sales. Hankering for uninhibited enjoyment includes material consumption (food, clothing, cell phones, splashy cars, expensive houses and furniture), but also promiscuous sex, alcohol and drug abuse, as well as spiritual highs offered by religious communities.

Popular postmodernity aggravates the problem in that it radicalises the emancipatory, utilitarian and hedonistic thrust of modernity. It scorns even the demands and constraints imposed by modernity, such as the authority of superiors, rigorous planning, consistent implementation, precision, efficiency, reliability, punctuality, relentless dedication, frugality, and the development and utilisation of all potentials available. With this it misleads traditionalists into believing that the fruits of modernity can be enjoyed without paying the price.
Newcomers tend to bypass the discipline of modernity on their way from traditionalist frugality to postmodern extravagance, assuming that the wealth generated by modernity belongs to all and is there for the taking. They believe themselves to be entitled to the immediate gratification of all their needs and desires. They fall into debt, turn promiscuous, fall victim to alcohol and drugs, and turn to crime. They may end up in slums, not find work, believe that they are deprived of their share in the wealth of the nation, start to riot and become vulnerable to demagogues and radical ideologies.

On the one hand, the obsession with material consumption leads to crime. It is common knowledge that South Africa is one of the crime capitals of the world. On the other hand, it leads to high levels of indebtedness. The consumption patterns of higher income earners always set criteria for what is considered a normal or acceptable standard of living. The more recent wave of economic growth was fuelled by personal extravagance funded by debt. To increase market share, financial institutions offered easy access to what is euphemistically called 'credit'. When their customers become unable to service their debts, they offer 'debt counselling' and 'debt restructuring', rather than promoting responsible financial behaviour.

In South Africa some $70 \%-80 \%$ of the income of regular income earners is precommitted to debt servicing. In some affluent Western countries the situation is much worse.

The figures are frightening. Out of the 17-million people who have some form of debt, $47 \%$ have fallen more than three months in arrears with their payments. That means that nearly eight million South Africans are over-indebted. (Fisher-French 2010:n.p.)

South Africans spend about 78c in every R1 to service their debt. People in some income bands were borrowing to live. Standard Bank has been actively involved in proactively restructuring R30bn in loans. (Helen Susman Foundation 2012)

\section{Economic consequences}

All over the world we witness the rapid development of a system of economic centres, sub-centres, peripheries and excluded regions on local, regional and global scales. The centres suck the best economic potential out of the peripheries, including entrepreneurial initiative, educational competence, professional expertise, vocational training, natural resources, capital and purchasing power. The economic peaks are highly integrated through communication and transportation networks, whilst the economic troughs are isolated from each other and dependent on the centres (Nürnberger 1999:39-69).

The centre-periphery structure of the economy in South Africa has not been caused, but seriously and deliberately exacerbated by apartheid policies in favour of White privilege and power at the expense of the Black population. For an economic analysis see Nürnberger 1988, Part I. Although racial discrimination heavily enhanced this development, it can also be observed in most other social contexts, notably the USA, the richest country in the world. 
The bulk of the traditionalist population in South Africa has made vast strides in the direction of modernity over the last half century. But the distribution of life chances has become severely unbalanced, notably access to education, training, resources, capital, land, communication, health care, and income. Cultural impediments, ruthless competition and the abuse of power by elites have rendered South Africa the most uneven society in the world, followed by Brazil. In 2009 the top $10 \%$ of the South African population received $51.7 \%$ of the income, in Brazil they received $42.9 \%$. The lowest $10 \%$ of the population in South Africa received 1.2\% of the income, in Brazil they received 0.8\% (World Bank 2012).

The struggle between enterprises, whether large or small, for greater market shares and higher profits leads to cost cutting exercises, largely at the expense of workers. Unskilled labourers, still in the majority, increasingly become redundant in terms of the modern economy. As a factor of production, labour can no longer compete with capital. Energy based on fossil fuels is more productive than energy based on muscle power. Machines are generally more efficient than humans. Brain power is progressively being replaced by electronic information systems. In affluent societies the redundant workforce is absorbed by the 'service sectors'. In underprivileged countries unproductive employment saps the meagre means available to the society. Bloated state bureaucracies, social grants and corruption severely drain the financial resources of less developed economies.

The self-interested motivations guiding modern institutions fuel economic discrepancies. Labour unions fight for higher wages and better working conditions at the expense of marginal workers and work seekers. Trade unionists again point to the exorbitant remuneration, incentive and bonus packages that top managers grant themselves, even if they had run down their enterprises:

[T] he median pay of executive directors of the top 40 JSElisted companies increased by $23.3 \%$, to $\mathrm{R} 4.8 \mathrm{~m}^{\prime}$ and short-term 'incentives' to executive directors, which include all cashbased payments made to an individual based on company and individual performance, rose even faster in these top 40 companies, by $57.5 \%$, to $\mathrm{R} 3.8 \mathrm{~m}$. (PricewaterhouseCoopers in Chilwane 2011)

Workers also loathe the attitude of share holders who make no productive contribution to the proceeds of a company, yet insist on cost reductions at the expense of jobs for the sake of higher bottom lines.

The urge to make money at all costs, found across the social spectrum, has serious social and economic consequences. Almost half the South African potential working population is not integrated in the formal economy. The younger generation is particularly vulnerable:

[M] ost of the affected youth will never find sustainable economic activity ... they will never acquire the everyday orientations to enable them to become self-reliant and productive citizens. They are condemned to live off handouts from older relatives, the sparse returns of state grants and the promises of politicians ...
We face the near certainty of tragically 'redundant' generations, with all the associated problems of demoralisation, boredom and lack of any status in the community. These young people are vulnerable to self-destructive behaviour, sexual profligacy, HIVAids, petty crime, prostitution or near pathological motherhood in the expectation of meagre child grants. This is a national disaster far more destructive than any other problem in our society. (Schlemmer 2011)

Enterprises are no longer willing to train new entries into the labour market. High levels of unemployment have led to extensive dependency on social grants and the overextension of state budgets. Whilst adult and able bodied South Africans cannot access social grants, they often depend on those received by eligible family members. In 200913 million people received social grants, of whom 9 million were children (Khumalo 2009). These measures alleviate the harshest effects of poverty in a seriously skewed economy, but they are clearly no solution to the problems of a system that is out of kilter (Neves 2009). Apart from unintended effects, experts warn us that the current level of social support by the state is economically unsustainable in the long run.

Another consequence of artificially induced collective avarice is that not only individuals, but states have become accustomed to living beyond their means. The government of the most prosperous country in the world today, the United States of America, has accumulated the most astronomical debt burden in world history. At the time of writing (30 August 2012), the US national debt amounted to roughly $\$ 16$ trillion, which is more than $\$ 50000$ per citizen. It is also rising rapidly. Total US debt was almost $\$ 57$ trillion (http:/ / www.usdebt.org/). Ironically this debt is co-financed by the proceeds of an exceptionally hardworking and frugal emergent economy, namely, 'communist' China.

The costs of an escalating budget deficit are offloaded on future generations. Printing money to offset the debt burden inevitably leads to inflation, and inflation again drains the resources of the poorest most. Anybody with a sober mind will have to concede that there is something seriously irrational with an economic system that creates such discrepancies and imbalances. Yet few people ever reflect on the underlying assumptions of the system, which are the typical assumptions of modernity.

\section{Ecological consequences}

The assumption that humans are entitled to become sole masters, owners and beneficiaries of reality has led to the deprecation of this reality as a whole. Reality (including the human body) has lost the dignity of a creation of God. It has become a quarry mined to satisfy personal desires and collective interests. Uninhibited greed blinds those people who have access to information to the facts exposed by serious social, economic and ecological research. Some researchers have mercenary relationships with powerful corporations and their lobbies.

The exponential rise of the human population over the last four centuries and the exploding material expectations 
generated by modernity has led to the progressive depletion of nonrenewable resources (notably fossil fuels), the overexploitation of renewable resources (notably forests, agricultural land and fish resources) and the 'blockage' of natural sinks (notably water and air pollution).

Futurological projections have shown for some decades now that humanity is likely to run out of sufficient water, agricultural land, food, and energy resources within the current century. A catastrophe of unprecedented proportion seems to be inevitable. But such information is, in practice, largely ignored. Naturally the worst offenders are also the least likely to come to their senses because they benefit most from these practices, and they are the most capable of cushioning the fallout in their private lives. The poor masses, on the other hand, have other things to worry about than global warming. A population in denial cannot easily be led to better insights even by a leadership that is ecologically well informed, yet wants to remain in power.

\section{The destruction of life on earth}

Natural causes of extinction are unavoidable. It is estimated that $99 \%$ of all species that ever lived have become extinct. Evolution goes hand in hand with extinctions. If the dinosaurs had not died out, mammals, thus humans, would not have had a chance to flourish. But natural processes are generally very slow. The average life-span of most species is estimated to be about 10 million years, with great differences between different species. Of course, there are also more sudden catastrophes. The dinosaurs probably died out as a result of a natural catastrophe.

But a new factor has come into the equation. Current extinctions have become overwhelmingly induced by human encroachments. They have been potentiated by the immense growth in human productive and destructive power: eradication of dangerous, useless or undesirable species (called weeds or pests), destruction of ecosystems (such as slash and burn agriculture), pollution of air and water (such as global warming and contamination through toxic waste), over-exploitation of natural resources (such as forests and fish resources), technological disasters (such as oil spills and nuclear pollution), and modern means of warfare.

As a result of the rapid rise in human demands on the natural environment, extinctions increase exponentially. Estimates and interpretations vary vastly. Whereas 200 years ago there was a negligible number of endangered species, at least 100000 species are now estimated to die-out per decade, but the figure is probably much higher (McKee 2009:300-308). Some palaeontologists believe that we are currently experiencing the sixth great extinction wave the planet has undergone in its long history. Others simply dismiss ecological concerns as unfounded 'gloom and doom scenarios', or argue that what happens is entirely natural.

Our grandchildren will probably know who has been right and curse us for our short-sightedness! The point is that exponential growth curves feed upon themselves, reaching astronomic figures in relatively short running times. As a result, humanity may be undermining its own preconditions for survival. Food, water and energy resources are already in balance. The current economic processes will almost certainly collapse before the end of the century. Some experts go so far as to warn us that humanity will die out as a result of its own rapaciousness - and that within a foreseeable future. The earth just cannot afford this parasitic species much longer (Durand 2010:53-75).

Awareness of this danger is virtually nonexistent amongst the rank and file of our population. The callous slaughter of rhinos and elephants is exercising the imagination of financially secure nature lovers, and concern about global warming has reached the mass media, but the bulk of the population continues to further its private and collective interests. Even concerned politicians in countries harbouring the most widely informed populations are unable to effect fundamental changes in behaviour, because they do not want to be voted out of power. Most theologians continue to operate within the cosy shells of their inherited 'symbolic universes', or devote themselves to their particular social preoccupations, without reflecting on the overarching directions of cosmic history. Humanity seems to resemble a group of men fishing and drinking their beer, sitting on a raft that is drifting helplessly and rudderlessly towards a cataract.

\section{Spiritual consequences}

As mentioned above, the inherent dynamics of modernity undermine all traditionalist certainties. Traditionalists, thrown into a modern context, suffer a crisis of identity. Inherited knowledge systems, skills, statuses and roles no longer count. Respected leaders become unskilled labourers or work seekers. Self-worth and self-confidence suffer under spiritual deprivation (Nürnberger 2007b:170-205). Stung by Western arrogance, Westernised Africans highlight the excellence of their African cultural heritage. Much of African theology is an attempt to come to terms with this disjuncture between 'Western' and 'African culture'.

The modern subversion of all transcendent certainties and inhibitions has immense moral costs. Whilst humans have never been perfect, modernity has opened the sluice gates of desire, entitlement and indifference. There is a widespread collapse of meaning, a denial of communal and social obligation, the dissolution of family cohesion, a deficient (often absent) socialisation of children, and faltering concern for the well-being of future generations.

Post-modern culture does not help the situation either. Note that I do not refer to the sophisticated philosophical version called postmodernism in this context, but to the 'culture' or Zeitgeist of popular postmodernity. Assuming that all cultures and convictions are equally valid, it does not take any one of them seriously. There is no commitment. The commandment 'Don't do it!' has changed into the slogan 'Just do it!' which again turned into the spur 'Go and get it!' 
The popular mindset is characterised by corruption, low levels of efficiency and performance, negligence at the work place, crime, drug addiction, sexual and culinary extravagance, family violence, casual attitudes towards the law, reckless behaviour on streets and highways, and equivalent behaviour in other contexts. There is a general lack of accountability, foresight and provision for old age, medical needs and unforeseen circumstances. One cannot avoid the impression that popular postmodern culture represents run-away spiritual entropy.

To sum up thus far, modernity has led to unprecedented freedom, mastery, international networking, productivity, wealth and power amongst those who have internalised its assumptions and put them to effective use. At the same time it has led to vast discrepancies in life chances between relatively competitive and relatively uncompetitive sections of the population. It has also set humanity on a course that undermines the ecological preconditions of human survival and well-being. This is serious! If we cannot find a way to change the collective mindsets of the most powerful sections of the world population, humanity as a whole is in trouble.

\section{The loss of relevance of the Christian faith}

The biblical faith has a comprehensively redemptive agenda. Going through the Scriptures one is struck by the fact that what was believed to be the 'Word of God' in biblical times has always been God's creative and redemptive response to human needs and predicaments in various dimensions of life, from the prerequisites of biological survival, through communal, social, economic and political order and viability, to spiritual authenticity. Towards the end of biblical history a vision of comprehensive well-being had emerged. The eagerly expected transition to a 'new creation', although spiritualised and otherworldly, spawned changed patterns of behaviour in the present ( $\mathrm{Rm} 6)$.

What has become of that in modern times? For any critical observer it is clear, I think, that under the impact of modernity the Christian message is rapidly losing its credibility, status and power in society. In secularised European countries only very few people still attend church services on a regular basis and it seems that we, in South Africa, are moving in the same direction. Just observe which societal groups are over and underrepresented at regular church services in any of the main line churches! Or compare average church attendance with average attendance of premier league football matches!

Why do we experience this kind of marginalisation? Firstly and most fundamentally, modernity is all about emancipation. The insistence of faith on accountability to a higher authority clashes with modern claims to mastery, ownership and entitlement. Communal expectations, typical of genuine Christian faith commitments, inconvenience individual autonomy and privacy. Popular postmodernity has taken the emancipatory drive to extremes. Religion must be fun, otherwise there is no demand for it. Conviction and commitment are no longer part of the agenda.
Secondly, modernity has elevated the enjoyment of life to the status of a 'holy cow' that cannot be touched. Abstract appeals to 'responsible behaviour' by well meaning campaigns against the spread of the HI virus, for instance, hardly ever dare to question the right to unconstrained sexual enjoyment. The gospel may be popular when its proponents promise ecstatic experiences, financial success and the legitimation of desired life styles, but the invitation to share in the cross of Christ - including obligations, constraints and sacrifices for the sake of suffering contemporaries, future generations and the natural world - is not necessarily very attractive.

Thirdly, the various premodern worldviews found in the Bible have been severely compromised by modern scientific insights. The Christian appeal to an 'otherworldly' power renders it 'superstitious' in the eyes of scientifically and technologically informed people. Claims to biblical inerrancy or doctrinal infallibility, demonstrably spurious, undermine the integrity of believers and the credibility of their message. Most of contemporary theology still operates within the 'symbolic universe' of a prescientific tradition, rearranging its antique furniture, as it were, without bringing it up to date. It seems oblivious of the breathtaking growth of scientific insight, or threatened by the dramatic changes in worldview since the Reformation. Pannenberg (1971:351) warned that, unless theology can account for the meaning of the word 'God', it may 'fall into the hopeless and indeed self-inflicted isolation of a higher glossolalia and draw the entire church with it into this cul-de-sac.' This is serious.

Bold reconceptualisations of the Christian faith by some modern theologians cause anger and consternation amongst their conservative colleagues and hardly filter through to the level of the average Christian community. It would seem that biblical, doctrinal and institutional fundamentalisms survived the modern onslaught best, which is understandable in a situation of incessant flux and uncertainty, yet it is out of step with the character of the biblical witness.

\section{Examples of such initiatives are:}

- the 'liberal theology' of the 18th and 19th centuries

- the response of Schleiermacher to the idealism of Kant and Hegel

- the historical-critical research of the Bible

- the Social Gospel movement in America

- Rudolf Bultmann's programme of demythologisation

- the wave of emancipatory thought in theologies based on Marxian social analysis, liberation and empowerment

- postmodern attempts to open up spiritual constraints and dismantle 'grand theories' and 'foundational narratives'.

Fourthly, by and large we have not mastered the use of contemporary means of communication. Pastors and priests are generally not trained in modern techniques of communication, and are largely ignorant of what drives the social processes today. The modern value system infiltrates individual and collective consciousness through radio, television, the Internet and cell phone networks such as Twitter and Facebook. These media reach out into the most 
remote rural areas and the poorest informal settlements twenty four hours a day. The best brains are recruited and the most sophisticated methods are used to lure potential buyers to new and rapidly obsolescent goods. Compare that with one hour of ancient hymns, strange liturgical formulations and sermons containing spiritual reassurances and moral precepts to an elderly flock on Sunday mornings (Swimme 1996:8-20).

Fifthly, Christian self-confidence has waned in secular societies. Faith is tolerated, rather than respected in public, and even that only as long as it does not interfere in the dimensions of life that really matter: politics, the economy, financial matters, sexual behaviour, science and technology. There is something awkward and unbecoming in revealing one's religious convictions on the stock exchange, in the laboratory, or in competitive sport. Faith has become a private pastime that believers tend to hide in public because they do not want to be branded irrational, otherworldly, sanctimonious, or superstitious spoilers.

The perceived scope of the Christian faith by believers themselves does not help in building public awareness and responsibility either. Ever since Pietism appeared on the scene (which was the spiritual counterpart of the emancipatory drive of the Enlightenment), the Christian faith concentrated on spiritual needs at the expense of the body, on the individual at the expense of the community, on the church at the expense of society, and on the human being at the expense of nature.

The powerful emphases of various contextual theologies on particular social and economic issues (liberation theology, Black theology, African theology, feminist theology, gay theology), though certainly justified and timely as such, tended to overlook the overarching historical context, the growing impact of modernity on our population, and its disruptive impact on a community still determined by traditionalist assumptions. In fact, these theologies are in many ways not only responses to, but also expressions of, the emancipatory drive of modernity.

Of course, there are new ventures that have more comprehensive horizons in terms of time and space, such as Hans Küng's Global Ethic Foundation; ecumenical movements dedicated to 'justice, peace and the integrity of creation'; local initiatives such as the Network of Earthkeeping Christian Communities in South Africa, the journal Sojourners, authors such as Teilhard de Jardin, John Cobb, Jürgen Moltmann, Rosemary Radford Ruether, Sally McFague (1997) and many others. What is needed is that such initiatives become sufficiently persuasive, coordinated and applicable to trigger a ground swell of awareness and reach a critical mass in society.

All this must be based on sound scientific research, realistic assessments of current social realities, and foundational theological reflections. Let me close this essay with a few pointers towards the latter. The reader should remember, however, that this essay was meant to draw attention to the neglected context of theology in our times, rather than to show how theology should respond to this context. To do justice to this task would necessitate another article, to say the least. I have proposed detailed theological approaches to this cluster of problems in other publications and do not have to repeat them here (Nürnberger 1988:287-319; 1998:223-241; 1999:156-185, 227-266; 2007a:25-87; 2007b:56-152-159, 234242; 2011:47-56, 203-270). In what follows, I simply highlight a few starting points for the development of such a theology.

\section{The redemptive message of the Christian faith}

Firstly, to regain its credibility, relevance and effectiveness as an expression of God's creative and redemptive project, the Christian faith must rediscover its fundamental assumptions and reconceptualise them in response to contemporary needs and in terms of current insight. Throughout biblical history, the 'Word of God' was God's creative and redemptive response to changing human needs, predicaments, depravations and worldviews. We have to do for our times what the biblical authors did for theirs.

The attempt to apply some 'orthodox' formulations of the past, such as the doctrine of the 'Trinity' or the 'kingdom of God', on the current situation will not suffice. How can we proclaim, for instance, that an eschatological 'kingdom' will come with power and bring about a dispensation void of depravity, scarcity, suffering, and death, when we know that reality cannot exist and function without the entropic process, that life presupposes the death of other life, or that social structures and processes tend to overwhelm individual means and motivations? We must realise that these formulations are metaphors and visions expressing what ought to become, rather than predictions of what will become.

Secondly, in formal terms, the biblical God must be conceptualised as the transcendent Source and Destiny of reality as such and as a whole. This statement precludes all forms of Deism, which posits a withdrawal of God from God's ostensibly 'autonomous' creation. It also precludes all forms of a 'God of the gaps' that posits divine interventions at junctures of cosmic evolution not (yet) accounted for by the sciences. It precludes the assumption of 'spaces' for 'non-interventionist direct divine action' within a causally underdetermined cosmic process (Russell, Murphy \& Stoeger 2008). It also precludes the popular attribution of desirable events to God and undesirable events to human sin or the devil.

Thirdly, as the transcendent Source and Destiny of reality as a whole, God cannot be thought of as a 'supernatural' factor within immanent reality, competing or cooperating with other such factors. God's intentionality, initiative and agency do not obviate human intentionality, initiative and action, 
but evoke and empower them. Faith in God does not shift human responsibility and initiative to divine responsibility and initiative, but becomes actively involved in this divine responsibility and initiative. Seemingly autonomous networks and processes within reality, and the regularities according to which they function, do not exclude their transcendent derivation. God does not work alongside causal networks and complexities, but through them.

Miracles, for instance, are unexpected, awe-inspiring and beneficial events, but they do not imply that God suspends or overrides the laws of nature, or that God's action was restricted to 'gaps' in causal networks caused by quantum uncertainty, probability, sensitivity to initial conditions, chance, or other factors. As the Creator of reality, God has entrenched causal networks, regularities and contingencies in this reality, because without them cosmic reality would not be able to exist and function. God is not likely to suspend or override them just to satisfy our private or collective interests. In tackling the issues discussed above, therefore, we must be earth-bound and pragmatic, rather than expecting supernatural divine interventions.

Fourthly, as the Creator of the world, God always stands for the whole of reality. Rightly understood, therefore, God consciousness will lead to the most comprehensive horizons attainable under particular cultural and historical circumstances. It will place the ego into the context of the body, the community, the society, humanity, the plethora of living creatures, the earth, the solar system, the galaxy, and beyond. Awareness of these concentric horizons is of critical importance for any responsible approach to the economic and ecological problems described above. God is not a handy helper who is always ready to fulfil our individual and collective needs, but the Creator of the universe of which even our earth as a whole is but a miniscule part. Spiritualisation and individualism amongst believers betray a truncated concept of the gospel.

Fifthly, as Pannenberg (1983:63ff) has taught us, faith in God brings about an eccentric (rather than egocentric, ethnocentric or anthropocentric) point of reference. Faith sees reality from above, as it were, with the eyes of God. This 'objectifying' view from above is a prerequisite for the development of a sense of freedom from reality and responsibility for reality. The naturalist alternative espoused by Richard Dawkins, Stuart Kauffman and many other natural scientists leads, on the one hand, to the absolutisation of the world, and on the other hand to the absolutisation of the human being as master, owner and beneficiary of the earth (Nürnberger 2011:174-183). That is precisely what happens under the impact of modernity.

Of course, being involved with nature and society most intimately, scientists, whether naturalists or believers, tend to possess a much greater sense of responsibility over against economic and ecological concerns, than Christian believers engulfed in their spiritual selfishness and truncated views of reality. However, it remains true that without a 'view from above', the individual will be submerged in reality like a fish in water, without orientation, being tossed around by desires and lures, fashions and fads, adverts and entertainment, ideologies and demagogues. Such people will lack a vision that transcends the immediate and the normal. They will remain oblivious of the needs and predicaments of others who are not part of their immediate spheres of interest, including those of future generations.

Sixthly, in substantive terms, the biblical faith is centred on God's creative and redemptive intentionality as it disclosed itself in the history of Israel, culminating in the Christ-event. Prophetic pronouncements increasingly emphasised God's vision of comprehensive optimal well-being for God's creation as a whole. However, a vision is not a prediction. God's vision involves us in a dynamically evolving apprehension of what ought to be, triggered by the experience of what ought not to be, and galvanising us into redemptive action.

The traditional promise-fulfilment scheme must be abandoned because it is static and unrealistic. It undermines the credibility of our message because prophetic pronouncements have hardly ever materialised as originally envisaged. We must respect them as visions of what ought to be, often articulated in symbolic and metaphorical terms, in response to their own historical circumstances, and spawning warnings and reassurances in particular historical situations.

In view of the law of entropy, scientific projections of the future of the universe, and the dependence of the human spirit on the biological body, it is no longer meaningful to project an ideal state of affairs without suffering and death into an 'eschatological future'. Overlooking their historical evolution over a millennium of biblical history, future expectations found in the Bible can best be reconceptualised as God's vision (thus our vision) of comprehensive optimal well-being. This vision translates into God's concern (thus our concern) for any deficiency in well-being in any dimension of life, and which functions like a retreating horizon that opens up ever new vistas, challenges and opportunities (Nürnberger 2011:244ff).

Seventhly, the Christian faith is constituted by the cross of Christ, and the elevation of his new life for others in fellowship with God to universal accessibility, validity and significance through what the tradition calls his 'resurrection from the dead' and 'ascension to the right hand of God'. The crucifixion of Christ must be seen as the self-sacrifice of God given to sinful humanity through his messianic representative, rather than a sacrifice given to God by humans.

It is the cross of Christ that defines the intentionality of God in very specific and exclusive terms as God's suffering, transforming acceptance of the unacceptable. This formulation is a translation, from legal into communal terms, of the classical (Protestant) gospel of justification by grace, accepted in faith, rather than through moral achievement 
or excellent disposition. (For the biblical background see Nürnberger 2002, chapter 10). An explication is found in Jürgen Moltmann's The Crucified God (1974), which built on Paul's kenotic understanding of Christ's mission and Martin Luther's juxtaposition of the 'theology of the cross' and the 'theology of glory'. This formulation of the gospel implies that we cannot tackle the problems discussed above without first owning them and being willing to suffer under them.

Eighthly, at the personal level, the forgiving partner must always bear the consequences of the guilt that the forgiven partner should have borne. God forgives not to condone evil, but to overcome evil in God's fellowship. However, divine intentionality and its impact on human consciousness cannot be restricted to private spiritual concerns. Faith liberates and empowers us to discern God's sacrificial intentionality as operative in the whole of cosmic reality. There is no benefit without cost, no life without death, no progress without effort, no evolution without entropy (Nürnberger 2011:222$225 ; 258-260)$.

God's sacrificial intentionality is at work in the agonies of struggling human beings, the suffering of living creatures, the vulnerability of the earth's ecosphere, the burning up of our sun, and the death of stars. The entropic process is the price God pays (and we have to pay) for having the kind of world God created. The possibility of a tsunami is the price God pays (and we have to pay) for having an earth's crust that can accommodate the evolution of life. The inevitability of death is the price God pays (and we have to pay) for having life in the first place. The potential of making wrong decision is the price God pays (and we have to pay) for having a creature endowed with freedom and responsibility.

Ninthly, God invites us to participate in God's creative, redemptive and sacrificial project in the world. This includes all the problems discussed in the first part of this essay. It has nothing to do with 'sanctification', or 'morality', or 'virtues'. It has everything to do with becoming part of God's mission. This participation materialises in limited and specific, but substantial 'gifts of the Spirit', in which God's power and love manifest themselves. They cover all motivations to 'make the world a better place' and all empowerments to do so in all spheres of life.

Rightly understood, therefore, God's vision of comprehensive optimal well-being cannot possibly mean that the individual, community or society should or could be capable of addressing all these issues all at once and single-handedly. But it does mean that such a vision must take root in the population, gain a critical mass, and branch out in countless particular tasks and responsibilities, including bold political and economic initiatives. That would provide the collective motivation to tackle the problems enumerated in the first part of the essay in multiple ways.

The 'gifts of the Spirit' must under no circumstances be restricted to the phenomena Paul described in 1 Corinthians $12-14$, as some Pentecostal and Charismatic movements tend to do. The Reformation emphasised the fact that Christians serve God's purposes in their secular professions, utilising their status and expertise as gifts of God to the 'glory of God'. However, as Luther emphasised, God's glory is nothing other than his creative, redemptive and sacrificial concern for God's world.

Tenthly, all this means that believers need to take the interests, intentions and agonies of God more seriously than their own. Even spiritual interests can be self-centred. Peace with God must be defined as an undisturbed fellowship with God. However, the God we believe in is on the move. God has no peace whilst God's creation has not attained its goal of comprehensive optimal well-being. And those who live in intimate fellowship with God cannot have their private 'peace with God' either.

That is why Christians will never arrive, they will always be on the way with God, they will ever be confronted with what ought not to have become, and challenged to move forward to what ought to become. The so-called 'eschatological proviso' (salvation already now, but not yet), which played an important role in existentialist theologies of the 20th century, and which has recently been given radical postmodern expressions (for instance, Kearney 2001), should not provide us with an escape route from the world into which God has placed us into an 'apocalyptic' new heaven and earth that will never arrive (Nürnberger 2011:244-247).

\section{Conclusion}

The sciences have taught us that the reality we know, and that we believe God has created and continues to create, is fraught with profound and unavoidable ambiguity. Without the abrasive and destructive process of entropic dissolution, reality would lack the productive energy to evolve and flourish. All higher creatures depend on the warmth and light that the sun sheds whilst slowly burning up. We all live on the crust of the earth that is subject to tectonic shifts causing earth tremors and tsunamis. Without death there can be no forms of higher life. Without the possibility of making wrong decisions, there would be no freedom and responsibility.

Assuming that this is the reality that God had created and that God considered 'very good' (Gn 1), we have to realise that it is God who pays the price for us to live and prosper. Seen in this light, the cross of Christ, where God exposed God-self to the enmity and depravity of humanity, is the prototypical expression of an all-encompassing creative and redemptive process. And God invites us to participate in God's sacrificial, creative and redemptive activity so that other creatures may live and prosper.

There is absolutely nothing more important in modern times than the message of God's suffering, transforming acceptance of the unacceptable. We are invited to participate in God's benevolent and sacrificial intentionality and agency. To make a substantial impact and gain a critical mass within the world population, this message must be proclaimed from the roof 
tops and lived out in all dimensions of secular life. What is at stake here is not the arrogance of a self-indulgent religion, but the commitment of God, the transcendent Source and Destiny of reality, to the comprehensive optimal well-being of God's creation as a whole, including humans of all cultures and persuasions.

\section{Acknowledgements Competing interests}

The author declares that he has no financial or personal relationship(s) which may have inappropriately influenced him in writing this paper.

\section{References}

Ashforth, A., 2005, Witchcraft, violence and democracy in South Africa, Chicago University Press, Chicago and London.

Bey, T., n.d., Top 10: Richest Men of All Time, viewed 24 July 2012, from http://www. askmen.com/top_10/entertainment/11_top_10_list.html

Chilwane, L., 2011, 'Cosatu angered by median pay increase for executives', The New Age, 30 July 2011, viewed n.d., from http://www.thenewage.co.za/22780-9-53-

Durand, F., 2010, 'The Rise of the Human Predator and the Transcendence of Consciousness', in C. Du Toit (ed.), Homo transcendentalis? Transcendence in Consciousness', in C. Du Toit (ed.), Homo transcendentalis? Transcendence in
science and religion: Interdisciplinary perspectives, pp. 53-75, Unisa Research science and religion: Interdisciplinary perspect
Institute for Theology and Religion, Pretoria.

Ehrlich, P.E. \& Ehrlich, A.H., 1998 [1996], Betrayal of science and reason: How antienvironmental rhetoric threatens our future, Island Press, Washington.

Fisher-French, M., 2010, 'Drowning in debt call this number', Mail \& Guardian, September 08 2010, viewed n.d., from http://mg.co.za/article/2010-09-08drowning-in-debt-call-this-number

Foster, B., 1994, The vulnerable planet: A short history of the environment, Monthly Review Press, New York.

Forde, G.O., 1969, The Law-Gospel Debate, Minneapolis, Augsburg Press.

Garner, R., 2000, Environmental politics: Britain, Europe and the global government, Macmillan Press, London.

Gore, A., 2009, 'An Inconvenient Truth, www.video.google.com', in The World Bank, viewed April 2012, from http://data.worldbank.org/indicator

Helen Susman Foundation, 2011, 'South Africa's Debt Trap - Indebtedness', in helen. suzman.foundation, viewed April 2012, from http://www.hsf.org.za/past-events/ quarterly-roundtable-series/quarterly-roundtable-series-south-africas-debt-trap

Kearney, R., 2001, The God who may be: A hermeneutics of religion, Indiana University Press, Bloomington.
Khumalo, G., 2009, 'Missions benefit from social grants', viewed July 2011, from http://www.southafrica.info/about/social/grants-060709.htm

McFague, S., 1997, Super, natural Christians: How we should love nature, Fortress Press, Minneapolis.

McKee, J.K., 2009, 'Contemporary Mass Extinction and the Human Population Imperative', Journal of Cosmology 2, 300-308.

Meadows, D., Meadows, D., Zahn, E., \& Milling, P., 1972 [updated 2004], The Limits to Growth, Universe Books, New York.

Mesarovic, M.D. \& Pestel, E., 1974, Mankind at the Turning Point, Hutchinson, London. Moltmann, J., 1974. The Crucified God, SCM, London.

Neves, D., Samson, M., Van Niekerk, I., Hlatswayo, S. \& Du Toit, A., 2009, 'The use and effectiveness of social grants in South Africa', in Plaas, viewed July 2011, from http://www.plaas.org.za/neves\%20social\%20grants.pdf

Neves, D., 2009, 'Going Beyond Basic Needs', in Plaas, viewed July 2011, from http:// www.plaas.org.za/neves\%20social\%20grants.pdf

Nürnberger, K., 1988, Power and Beliefs in South Africa, Unisa, Pretoria.

Nürnberger, K., 1994, 'Law and Grace', in C. Villa-Vicencio \& De Gruchy, J. (eds), Doing Ethics in context: South African perspectives, pp. 62-74, Orbis, Maryknoll, NY/ David Philip, Cape Town.

Nürnberger, K, 1999, Prosperity, Poverty and Pollution: Managing the Approaching Crisis, Cluster Publications, Pietermaritzburg/Zed Books, London.

Nürnberger, K., 2002, Theology of the Biblical Witness, LIT-Verlag, Münster.

Nürnberger, K., 2007a, Making ends meet: Personal Money Management in a Christian Perspective, Cluster Publications, Pietermaritzburg.

Nürnberger, K., 2007b, The Living Dead and the Living God: Christ and the Ancestors in a Changing Africa, Cluster Publications, Pietermaritzburg.

Nürnberger, K., 2011, Regaining Sanity for the Earth, Exlibris Corporation, London/ Cluster Publications, Pietermaritzburg.

Pannenberg, W., 1971, Grundfragen Systematischer Theologie, 2nd edn., Vandenhoeck \& Ruprecht, Göttingen.

Pannenberg, W., 1983, Anthropologie in theologischer Perspektive, Vandenhoeck \& Ruprecht, Göttingen.

Rosenberg, M. Current World Population. Geography About n.d., viewed 26 January 2012, from http://geography.about.com/od/obtainpopulationdata/a/ worldpopulation.htm

Russell, R.J., Murphy, N. \& Stoeger, W.R. (eds.), Scientific perspectives on divine action, Vatican Observatory, Vatican/Center for Theology and the Natural Sciences, Berkeley, CA.

Schlemmer, L., 2011, 'How stable is South Africa?', Politicsweb, viewed Apri 2012, from http://www.politicsweb.co.za/politicsweb/view/politicsweb/en/ page 71619 ? oid $=2460$

Swimme, B., 1996, The hidden heart of the cosmos: Humanity and the new story, Orbis Books, Maryknoll, NY.

World Bank, n.d., 'Gross Domestic Income 2010 in US\$' viewed April 2012, from $\mathrm{http}: / /$ data.worldbank.org/indicator/NY.GNP.PCAP 